\title{
Tracking steps in oncology: the time is now
}

This article was published in the following Dove Press journal:

Cancer Management and Research

Juhi M Purswani'

Nitin Ohri ${ }^{2}$

Colin Champ ${ }^{3,4}$

'Department of Radiation Oncology,

New York University School of

Medicine, New York, NY, USA;

${ }^{2}$ Department of Radiation Oncology, Montefiore Medical Center, Albert

Einstein College of Medicine, New

York, NY, USA; ${ }^{3}$ Department of

Radiation Oncology, University of

Pittsburgh Medical Center, Pittsburgh,

PA, USA; ${ }^{4}$ Department of Integrative

Oncology, University of Pittsburgh

Medical Center, Pittsburgh, PA, USA

Correspondence: Nitin Ohri

Department of Radiation Oncology,

Montefiore Medical Center, Albert

Einstein College of Medicine, III East

210th Street, Bronx, New York, NY

10467, USA

Tel +I 7189207750

Email ohri.nitin@gmail.com
Purpose: Accurate evaluation of patients' health status is a key component of the workup, treatment, and follow-up of cancer patients. Assessments by clinicians (eg, performance status, toxicity grade) and patients (eg, quality of life) play a critical role in current practice but have significant limitations. Technological advances now provide an opportunity to track a new class of objective measures of patient activity, such as daily step counts. Here, we describe recent efforts to incorporate this technology into the field of oncology.

Design: We conducted a structured literature search using MEDLINE electronic database to identify published observational studies of tracking steps in cancer patients and trials of exercise programs for cancer survivors incorporating pedometers until February 2016.

Results: Data indicate that physical activity information may supplant existing scales for the assessment of cancer patients' functional capacity.

Conclusion: Objective activity monitoring is poised to revolutionize the way health care providers assess cancer patients at the time of diagnosis, during treatment, and in the survivorship setting.

Keywords: cancer, pedometers, fitness trackers, performance status

\section{Assessing the cancer patient}

Approximately $40 \%$ of the general population will be diagnosed with cancer, ${ }^{1}$ with the number of new cases expected to rise by nearly $70 \%$ over the next two decades. Fortunately, oncologic outcomes are improving, and advances in cancer detection and management have increased 5-year survival rates to $\sim 70 \% .^{2}$ As the number of cancer cases and cancer survivors continues to climb, it is imperative that we explore novel methods of evaluating our patients and tracking their progress through treatment and survivorship.

In current practice, health care professionals primarily assess patients' functional status using clinician-reported measures. Performance status (PS) is a semiquantitative score assigned by clinicians based on a patient's apparent physical abilities and activity level. Commonly used PS scales for adult patients include the Karnofsky scale and the Eastern Cooperative Oncology Group (ECOG)/Zubrod scale. While these tools are ingrained in the clinical research arena and may be used to guide routine clinical care, they have significant limitations. Important weaknesses of these tools include large interobserver variability and difficulty in capturing changes in PS using discrete PS categories. ${ }^{3-5}$ In a study comparing physician assessments to objective measurements, $80 \%$ of patients who were assigned ECOG PS scores of 0 or 1 actually spent $>50 \%$ of waking hours resting, which corresponds to a PS score of $3 .{ }^{6}$ There is a large variation within ECOG PS categories that necessitates more detailed and discriminate assessment of physical function than what is captured. 
Increasingly, patient-reported outcomes (PROs) are recognized as important assessment tools that may have more relevance than clinician-scored measures in certain settings. ${ }^{7}$ However, self-administered instruments may suffer from recall bias, poor-quality reporting, and missing or inconsistent data. ${ }^{8}$ The utility of PROs may be particularly compromised in patients with impaired cognitive function, literacy, or fluency. ${ }^{9}$ Furthermore, frequent acquisition of PRO data may be burdensome for cancer patients.

Recent technological advances may be leveraged to provide objective, quantitative, and dynamic information describing our patients' physical activity levels captured by measuring step counts. Here, we review studies that track steps in oncology. We focus on the role of step counts captured using pedometers and accelerometers in assessing the PS of cancer patients. While other forms of objective patient assessment exist, step counts can be measured using simple low-cost single-unit devices worn on the body continuously. Pedometers and accelerometers require infrequent battery replacements with low burden to patients. Data are accessible and captured in real-time as a metric that is easy to conceptualize over other forms of objective data such as pulse oximetry, heart rate, and sleep time. Patients may already be familiar with consumer grade pedometers, as well as health recommendations and goals specific to step counts that are publicized by companies such as Fitbit. We suggest steps that might help to establish step tracking as an important aspect of clinical cancer research and individual patient care.

\section{Significance of physical activity in cancer patients}

It is generally accepted that an active lifestyle is associated with health benefits in the general population. These benefits may include a reduction in the risk of developing malignancies such as colorectal and breast cancer. ${ }^{10}$ The importance of physical activity may be even greater for patients who are already diagnosed with cancer.

Patients with breast cancer, ${ }^{11}$ pediatric malignancies, ${ }^{12}$ hematologic malignancies, ${ }^{13}$ and other cancers ${ }^{14}$ are significantly less active when compared to healthy controls using various measures. Among cancer patients, specific diagnoses and treatment approaches have been associated with reduced activity levels measured with an accelerometer-based activity system. ${ }^{15}$ Physical activity has been linked with improved quality of life (QoL) ${ }^{16}$ reduced risk of disease recurrence, ${ }^{17,18}$ and prolonged overall survival ${ }^{19-22}$ in large studies.

Existing evidence supports a causal link between physical activity and improved cancer outcomes. Physical activity improves metabolic function, enhances physical fitness and mood, and reduces fatigue in patients undergoing cancer treatment. ${ }^{23-25}$ Randomized studies reveal an improvement in physiological and psychological function when exercise is implemented during radiation therapy (RT) for men treated for prostate cancer. ${ }^{26-28}$ Other benefits for these men included improved overall health-related QoL with respect to physical functioning, role function, social functioning, physique, and fatigue. ${ }^{29} \mathrm{~A}$ randomized trial demonstrated that resistance training during breast radiotherapy can counteract the inflammatory response to treatment and help reduce pain and fatigue..$^{30,31}$

Serum biomarker studies may provide insight about cancer patients' activity levels and the biochemical effects of physical activity. Exercise-induced myokines are a class of peptides and cytokines derived from muscle fiber and secreted during skeletal muscle contraction. Interleukin-6 is one such myokine whose levels in serum and muscle tissue increase after exercise. ${ }^{31}$ Assessing serum biomarkers may require invasive testing with high associated costs. However, given that the effect of increased activity levels on improved outcomes is likely multifactorial, an understanding of how levels of exercise-induced myokines change with physical activity may help us to identify the underlying mechanisms that link increased activity to improved health outcomes in cancer patients.

\section{Measuring physical activity}

There are several methods to measure physical activity in the clinical setting. Subjective methods include self-reporting instruments such as questionnaires and physical activity diaries. These methods are cost effective and commonly used for cancer-related research. The Godin-Shepard Leisure-Time Physical Activity Questionnaire (GSLTPAQ) is a four-item self-administered questionnaire used to assess mild, moderate, and strenuous leisure time physical activity. ${ }^{32}$ GSLTPAQ is widely used in oncology research and is one of the measures of physical activity recommended by the Division of Cancer Epidemiology and Genetics research program. ${ }^{33}$ While the GSLTPAQ has been validated in healthy adults ${ }^{32,34}$ and is often applied to cancer survivors, there are several limitations to its applicability in cancer patients undergoing treatment - many of whom in reality perform no leisure time physical activities. In a systematic review of 212 articles that reported using GSLTPAQ among cancer survivors, only three studies provided data correlating the GSLTPAQ Leisure Score Index with accelerometer or pedometer data. ${ }^{33}$ There was no study in which the primary aim was to evaluate the survey's 
validity in cancer survivors. Other limitations of the GSLTPAQ include the frequent use of classification systems disparate from that suggested by Godin ${ }^{32}$ in oncology research, potentially introducing cut point bias. ${ }^{33}$ Additionally, many studies have employed modified versions of the GSLTPAQ that have not been validated.

Technological advances now enable simple, costeffective, objective, and direct measurement of physical activity. In the medical field, fitness trackers are increasingly used to measure physical activity in a range of patient populations. Depending on the particular device selected, a fitness tracker can offer direct measures of physical activity in the form of step counts or indirect measures of acute and chronic PA: energy expenditure, heart rate, total sleep time, and sleep efficiency. ${ }^{35}$ Pedometer data have been validated against observational and self-reported data ${ }^{36}$ and correlate with theoretically related anthropometric parameters, such as age, weight, and body mass index..$^{37,38}$ Traditional pedometers, such as Yamax digiwalker SW-200®, are low-tech and low-cost simple detectors of steps and have been shown to be accurate in detecting steps taken. ${ }^{39} \mathrm{~A}$ step is recorded into the device when a vertical acceleration deflects a springsuspended lever arm above a designated force sensitivity threshold. A major limitation of these devices is that they are not sensitive to nonambulatory physical activities, such as cycling, swimming, and fitness training. ${ }^{40}$

Accelerometers have improved upon traditional pedometers and are now incorporated into numerous commercially available fitness trackers. These are small devices that record accelerations in gravitational units on one or more planes to provide an estimate of duration and intensity of movement. Common estimates of physical activity obtained from accelerometers can be divided into discrete measures: activity countbased, expenditure-based, intensity-based, posture-based, and steps. ${ }^{41}$ Activity count-based measures capture the intensity and duration of accelerations measured by the device in counts/ $\mathrm{min}$ /day and can subsequently characterize these movement signals into estimates of energy expenditure. Intensity-based measures define the hours spent in sedentary, light, moderate, or vigorous physical activity per day. Posture-based measures define the time spent per day lying, sitting, stepping, or standing. While step counts measured using accelerometers are similarly limited by a lack of sensitivity in capturing nonambulatory physical activity, pedometer- and accelerometer-derived step counts offer clinical utility in assessing the PS of patients in an oncologic setting. In this review, we focus on steps per day as estimated from the pedometer or accelerometer as it is a direct measure of physical activity.
The Fitbit ${ }^{\text {TM }}$ Flex (Fitbit Inc., San Francisco, CA, USA) uses a triaxial accelerometer - a measure of acceleration in three dimensions of space (vertical, anteroposterior, and mediolateral) - to estimate steps. This fitness tracker has been demonstrated to be reliable in healthy adults ${ }^{42}$ and people with stroke and traumatic brain injury. ${ }^{43}$ The ActivPAL ${ }^{\text {TM }}$ monitor (PAL Technologies Ltd., Glasgow, UK) reveals the time spent supine or sitting, standing, and stepping over a 24-hour period and can also estimate energy expenditure from activity counts. This instrument has also been validated, more specifically in hospital inpatients ${ }^{44}$ and community-dwelling older adults. ${ }^{45}$ The Misfit Shine (Misfit Inc., San Francisco, CA, USA) is another triaxial accelerometer that has been tested against similar tracking devices, demonstrating nearly the highest step-counting accuracy for measuring 200 steps (98.3\% accuracy, SD of 7.2) to 1000 steps (99.7\% accuracy, SD of 39.8$).^{46}$

While many older devices were limited in their use clinically because of the associated cost and technical requirements for their use, newer accelerometer-based pedometers have become extremely inexpensive compared to typical medical devices and procedures and contain longer battery lives exceeding 1 year, allowing users to wear them continuously. Unlike the ActivPAL which is worn at the hip, the Fitbit is worn on the wrist and is water proof, allowing for continuous and uninterrupted wear. Most devices now allow data to be downloaded wirelessly onto a computer or mobile device, and many companies provide a user-friendly interface for storing and analyzing data online. Patients, clinical or research staff can create individual online user accounts with easy data upload/download features allowing for real-time self-monitoring.

\section{Fitness trackers in oncology - observational studies}

Observational studies performed in healthy subjects and patients without cancer demonstrate that the use of fitness trackers is associated with increases in step counts and reduction in blood pressure and weight. ${ }^{47} \mathrm{~A}$ different spectrum of associations may be expected in a cancer patient whose function is impaired by disease burden and/or treatment-related toxicities. Recent observational studies trials have explored step counting in cancer patients. Some key findings are summarized below and in Table 1.

A study conducted in patients with incurable thoracic malignancies not only demonstrated a statistical correlation between daily step counts and ECOG PS but also revealed a wide range of step counts within PS categories. These 
Table I Observational studies of activity monitoring in cancer patients

\begin{tabular}{|c|c|c|c|}
\hline First author & Patient population & Pedometer model & Key findings \\
\hline Bennett $^{50}$ & $\begin{array}{l}32 \text { Patients undergoing bone } \\
\text { marrow transplant }\end{array}$ & $\begin{array}{l}\text { Fitbit }^{\mathrm{TM}} \text { Flex (Fitbit Inc., San } \\
\text { Francisco, CA, USA) }\end{array}$ & $\begin{array}{l}\text { Within-patient decreases in daily steps associated with increases } \\
\text { in pain (beta }=-852 ; 852 \text { fewer steps per unit increase in pain } \\
\text { score, } p<0.00 \mathrm{I} \text { ), fatigue (beta }=-886, p<0.00 \mathrm{I} \text { ), and other patient- } \\
\text { reported toxicity scores }\end{array}$ \\
\hline Champ ${ }^{53}$ & $\begin{array}{l}\text { I0 Women with early- } \\
\text { stage breast cancer post- } \\
\text { lumpectomy undergoing RT } \\
\text { and ECOG PS 0-I }\end{array}$ & $\begin{array}{l}\text { Misfit Shine (Misfit Inc., San } \\
\text { Francisco, CA, USA) }\end{array}$ & $\begin{array}{l}\text { Step counts decreased by } 54 \text { steps/day from baseline (RT planning } \\
\text { simulation) during RT ( } p<0.00 \mathrm{I} \text { ) (clinically nonrelevant due to } \\
\text { large number of data points); sleep amount did not correlate with } \\
\text { activity levels }\end{array}$ \\
\hline Ferriolli $i^{15}$ & $\begin{array}{l}\text { I62 Cancer patients } \\
\text { undergoing a variety of } \\
\text { treatments }\end{array}$ & $\begin{array}{l}\text { ActivPAL }{ }^{\mathrm{TM}} \text { monitor (PAL } \\
\text { Technologies Ltd., Glasgow, } \\
\text { UK) }\end{array}$ & $\begin{array}{l}\text { Patients with advanced cancer took } 45 \% \text { fewer steps }(p=0.00 \mathrm{I}) \text {, } \\
\text { I week after surgery for upper } \mathrm{Gl} \text { cancer time stepping/day } \\
\text { decreased by } 88 \%(\mathrm{I} .6 \pm 0.8 \text { to } 0.2 \pm 0.2 \mathrm{~h} / \text { day); there was a } \\
\text { significant correlation between WHO/ECOG score and time } \\
\text { stepping ( } r=0.586, p<0.00 \mathrm{I}) \text {; there was a significant correlation } \\
\text { between number of steps taken and EORTC QLQ-C } 30 \text {, } \\
\text { performance status, and } \mathrm{Q} \text { L scores }\end{array}$ \\
\hline Lowe $^{49}$ & $\begin{array}{l}\text { 31 Patients with brain } \\
\text { metastases receiving whole } \\
\text { brain radiotherapy }\end{array}$ & $\begin{array}{l}\text { ActivPAL monitor (PAL } \\
\text { Technologies Ltd., Glasgow, } \\
\text { UK) }\end{array}$ & $\begin{array}{l}\text { There was a difference between participants who spent } \geq 1.6 \mathrm{~h} / \\
\text { day in the standing position and reported } \mathrm{Q} \text { / } \text { scores (mean } \\
\text { between group difference }=1.0 ; 95 \% \mathrm{Cl}: 0.1-1.9 ; p=0.034 \text { ) }\end{array}$ \\
\hline Maddocks $^{48}$ & $\begin{array}{l}84 \text { Patients with advanced } \\
\text { lung cancer and ECOG PS } \\
0-2\end{array}$ & $\begin{array}{l}\text { ActivPAL monitor (PAL } \\
\text { Technologies Ltd., Glasgow, } \\
\text { UK) }\end{array}$ & $\begin{array}{l}\text { High step counts and increased time spent stepping associated } \\
\text { with favorable PS in patients with thoracic cancer ( } p<0.05 \\
\text { significant between group difference for all PS categories) }\end{array}$ \\
\hline Ohri ${ }^{52}$ & $\begin{array}{l}38 \text { Patients with head and } \\
\text { neck, lung, and Gl cancer } \\
\text { treated with concurrent } \\
\text { chemoradiotherapy and } \\
\text { ECOG PS 0-2 }\end{array}$ & $\begin{array}{l}\text { Vivofit (Garmin, Olathe, KS, } \\
\text { USA) }\end{array}$ & $\begin{array}{l}\text { Daily step count per } 1000 \text { steps (based on 3-day average) was } \\
\text { significantly associated with lower risk for hospitalization (HR } \\
=0.62 ; 95 \% \mathrm{Cl}: 0.46-0.83 ; p=0.002 \text { ), while most recent low global } \\
\text { QoL scores or impaired ECOG PS were not }\end{array}$ \\
\hline
\end{tabular}

Abbreviations: QoL, quality of Life; ECOG, Eastern Cooperative Oncology Group; EORTC QLQ-C30, European Organization for Research and Treatment Core Quality of Life Questionnaire-C30; PS, performance status; RT, radiation therapy; Gl, gastrointestinal; WHO, World Health Organization.

findings suggest that the ECOG scale may lack sufficient sensitivity to evaluate new supportive care treatments. ${ }^{48}$ In a series of patients receiving palliative radiotherapy for brain metastases, sedentary behavior was associated with inferior scores for depression, anxiety, and QoL. ${ }^{49}$ In a trial evaluating pedometers in adult patients undergoing hematopoietic cell transplant, reductions in patients' step counts were highly correlated with increases in pain, fatigue, and other patientreported toxicity scores..$^{50}$ Patients who undergo transplant commonly experience mucositis, characterized by painful mouth sores, as a side effect of therapy. Interestingly, in this study, patient-reported mouth sores did not correlate with daily step counts, while there was a significant link with pain scores and daily steps during the period of symptomatic mucositis. This reveals the role of step tracking in helping us to better identify which PROs correlate more reliably with the experience of symptoms and treatment side effects. A study performed in an inpatient oncology unit demonstrated that sleep parameters measured by wrist actigraphy are correlated with pain scores for patients with advanced cancer. ${ }^{51}$

Two more recent studies incorporated step tracking into the evaluation of patients as they underwent curative treatment for locally advanced cancers. In one study conducted in patients with head and neck, lung, and gastrointestinal cancers treated with concurrent chemoradiotherapy, 3-day recent average of step counts significantly correlated with hospitalization risk during treatment such that for every 1000 steps taken per day, there was a $38 \%$ decrease in risk for hospitalization. ${ }^{52}$ On the other hand, the most recent impaired ECOG PS and inferior QoL score was not associated with increased hospitalization risk. In another study conducted in patients with early-stage breast cancer treated with RT after lumpectomy, pedometer step counts and distance traveled were found to decrease slightly during RT. ${ }^{53}$ Although this was deemed nonrelevant clinically due to the large number of data points captured in the study, these findings certainly underpin the need to increase patients' physical activity levels during RT. Additionally, investigators reported that sleep measured using a fitness tracker was unaffected by treatment. These studies demonstrate that step tracking, as opposed to more subjective (ECOG and $\mathrm{QoL}$ ) and indirect measures of PA (sleep time), may more reliably predict the changes in physical activity during curative treatment that may increase the risk for poor health outcomes. 
Existing data already indicate that step counts can serve as a new class of vital signs in the evaluation and management of cancer patients. Larger clinical trials and ecological studies will be required to establish the utility of step counts in clinical care and identify the most meaningful activity metrics. As pedometers and accelerometers become ubiquitous in nonclinical settings, we can expect large studies of observational data that will corroborate trial findings. We anticipate

Table 2 Trials of exercise programs for cancer survivors incorporating activity monitoring

\begin{tabular}{|c|c|c|c|c|c|}
\hline First author & $\begin{array}{l}\text { Patient } \\
\text { population }\end{array}$ & $\begin{array}{l}\text { Control } \\
\text { intervention }\end{array}$ & $\begin{array}{l}\text { Experimental } \\
\text { intervention }\end{array}$ & Pedometer & Key findings \\
\hline Blaauwbroek $^{40}$ & $\begin{array}{l}38 \text { Adult survivors } \\
\text { of childhood cancer }\end{array}$ & - & $\begin{array}{l}\text { Home-based } \\
\text { PA counseling + } \\
\text { pedometer to measure } \\
\text { daily steps }\end{array}$ & $\begin{array}{l}\text { Yamax digiwalker } \\
\text { SW-200尺 }\end{array}$ & $\begin{array}{l}\text { Intervention significantly improved } \\
\text { fatigue scores from baseline to } 10 \text { weeks } \\
\text { post-intervention }(p<0.0005)\end{array}$ \\
\hline Frensham ${ }^{60}$ & $\begin{array}{l}9 \text { Sedentary cancer } \\
\text { survivors }\end{array}$ & - & $\begin{array}{l}\text { Pedometer used to } \\
\text { monitor daily steps } \\
\text { and report daily steps } \\
\text { and affective state on a } \\
\text { website }\end{array}$ & $\begin{array}{l}\text { Yamax digiwalker } \\
\text { SW-200 }\end{array}$ & $\begin{array}{l}\text { Participants increased daily step counts } \\
\text { by } 16 \% \text { from week } 2 \text { to week } 6 \text { of the } \\
\text { intervention }\end{array}$ \\
\hline Irwin 66 & $\begin{array}{l}75 \text { Breast cancer } \\
\text { survivors }\end{array}$ & Usual care & $\begin{array}{l}150 \mathrm{~min} / \text { week of } \\
\text { supervised gym and } \\
\text { home-based aerobic } \\
\text { exercise for } 6 \text { months }\end{array}$ & NA & $\begin{array}{l}\text { Intervention was associated with } \\
\text { increased moderate-intensity to } \\
\text { vigorous-intensity aerobic exercise vs } \\
\text { control (I } 29 \text { vs } 44 \text { min/week, } p<0.00 \text { I) } \\
\text { and increased average pedometer steps } \\
\text { vs control ( } 62 \text { vs } 60 \text { steps/day, } p<0.0 \text { I) }\end{array}$ \\
\hline James $^{61}$ & $\begin{array}{l}\text { I74 Cancer } \\
\text { survivors }\end{array}$ & $\begin{array}{l}\text { Wait-list group } \\
\text { who received } \\
\text { intervention after } \\
20 \text { weeks }\end{array}$ & $\begin{array}{l}\text { Six } 2 \text {-hour long } \\
\text { sessions delivered over } \\
8 \text { weeks } \\
\text { targeting healthy eating } \\
\text { and PA }\end{array}$ & $\begin{array}{l}\text { Yamax digiwalker } \\
\text { SW-200 }\end{array}$ & $\begin{array}{l}\text { Intervention was associated with } \\
\text { increased pedometer steps by } 478 \text { and } \\
\text { control decreased pedometer steps by } \\
\text { I } 282 \text { (adjusted mean difference: I } 76 \text { I } \\
{[184-3337, p=0.0028] \text { ) }}\end{array}$ \\
\hline Matthews ${ }^{64}$ & $\begin{array}{l}36 \text { Breast cancer } \\
\text { survivors }\end{array}$ & Usual care & $\begin{array}{l}\text { Single in-person } \\
\text { counseling visit and five } \\
\text { telephone-counseling } \\
\text { calls }\end{array}$ & NA & $\begin{array}{l}\text { Intervention was associated with } \\
\text { increases in activity levels over time vs } \\
\text { control (counts/min/day and steps/day } \\
{[p \leq 0.04] \text { ) }}\end{array}$ \\
\hline Mayo $^{63}$ & $\begin{array}{l}26 \text { Advanced } \\
\text { cancer patients } \\
\text { with fatigue }\end{array}$ & Usual care & $\begin{array}{l}\text { Pedometer-based } \\
\text { walking intervention } \\
\text { with individualized daily } \\
\text { step goals }\end{array}$ & NA & $\begin{array}{l}\text { Estimated effect of intervention on } \\
\text { improving fatigue was strong (range } \\
\text { across different correlation structures } \\
3.5-3.68 \text { ) }\end{array}$ \\
\hline Pinto $^{24}$ & $\begin{array}{l}86 \text { Sedentary } \\
\text { breast cancer } \\
\text { survivors }\end{array}$ & Usual care & $\begin{array}{l}\text { In-person PA } \\
\text { instructions + } \\
\text { pedometer to monitor } \\
\text { PA participation }\end{array}$ & Yamax digiwalker & $\begin{array}{l}\text { Intervention associated with greater } \\
\text { total minutes of PA }(p<0.00 \mathrm{I}) \text {, moderate- } \\
\text { intensity PA }(p<0.00 \mathrm{I}) \text {, and higher energy } \\
\text { expenditure/week }(p<0.00 \mathrm{I}) \text { vs control }\end{array}$ \\
\hline Short ${ }^{62}$ & $\begin{array}{l}330 \text { Breast cancer } \\
\text { survivors }\end{array}$ & $\begin{array}{l}\text { Brochure } \\
\text { describing } \\
\text { Australian PA } \\
\text { guidelines }\end{array}$ & $\begin{array}{l}\text { Patient-tailored } \\
\text { print intervention or } \\
\text { disease-targeted print } \\
\text { intervention }\end{array}$ & NA & $\begin{array}{l}\text { Tailor intervention significantly improved } \\
\text { self-reported resistance scores at } 4 \\
\text { months post-baseline - significant } \\
\text { reduction in the odds of not doing any } \\
\text { resistance-based PA ( } p<0.01) \text { vs control } \\
\text { and increased odds of meeting resistance } \\
\text { training guidelines by } 3.38 \text { at } 4 \text {-month } \\
\text { follow-up }(p<0.0 \mathrm{I})\end{array}$ \\
\hline Vallance $^{65}$ & $\begin{array}{l}377 \text { Breast cancer } \\
\text { survivors }\end{array}$ & $\begin{array}{l}\text { Standard public } \\
\text { health PA } \\
\text { recommendation }\end{array}$ & $\begin{array}{l}\text { Pedometer, PA print } \\
\text { materials, or both }\end{array}$ & $\begin{array}{l}\text { Yamax digiwalker } \\
\text { SW-200 }\end{array}$ & $\begin{array}{l}\text { PA increased by } 30 \mathrm{~min} / \text { week in the } \\
\text { control vs } 70 \mathrm{~min} / \text { week in the print } \\
\text { material group (mean difference: } 39 \mathrm{~min} / \\
\text { week; } 95 \% \mathrm{Cl}=-10 \text { to } 89, p=0.1 \mathrm{I} 7 \text { ), } \\
89 \mathrm{~min} / \text { week in the pedometer group } \\
\text { (mean difference: } 59 \mathrm{~min} / \text { week; } 95 \% \mathrm{Cl} \\
=\mathrm{II}-108, p=0.017 \text { ), and } 87 \mathrm{~min} / \text { week in } \\
\text { the combined group (mean difference: } 57 \\
\text { min/week; } 95 \% \mathrm{Cl}=8-106, p=0.022 \text { ) }\end{array}$ \\
\hline
\end{tabular}

Abbreviations: PA, physical activity; NA, not applicable. 
Table 3 Trials of exercise programs incorporating activity monitoring for patients undergoing active cancer therapy

\begin{tabular}{|c|c|c|c|c|c|}
\hline First author & Population & Control & $\begin{array}{l}\text { Experimental } \\
\text { intervention }\end{array}$ & Pedometer & Key findings \\
\hline Gokal $^{54}$ & $\begin{array}{l}50 \text { Breast cancer } \\
\text { patients receiving } \\
\text { adjuvant therapy }\end{array}$ & Usual care & $\begin{array}{l}\text { I } 2 \text { weeks of moderate- } \\
\text { intensity walking }+ \\
\text { pedometer to measure } \\
\text { daily step counts, provide } \\
\text { feedback and motivation }\end{array}$ & $\begin{array}{l}\text { Yamax digiwalker } \\
\text { SW-200® }\end{array}$ & $\begin{array}{l}\text { Intervention was associated with } \\
\text { improvements in levels of PA } \\
\left(x^{2}=17.15, p=0.001 \text { I }\right) \text {, fatigue } \\
(F=5.77, p=0.02) \text {, self-esteem } \\
(F=8.93, p \leq 0.001) \text {, and mood scores } \\
(F=4.73, p=0.03)\end{array}$ \\
\hline Javaheri ${ }^{57}$ & $\begin{array}{l}\text { 2I Patients with breast } \\
\text { and head and neck } \\
\text { cancer undergoing } \\
\text { radiation therapy }\end{array}$ & - & $\begin{array}{l}\text { Pedometer-based } \\
\text { walking intervention with } \\
\text { individualized weekly } \\
\text { step-count goals }\end{array}$ & $\begin{array}{l}\text { SenseWear Pro } \\
\text { Armband }\end{array}$ & $\begin{array}{l}\text { Improvements in happiness using } \\
\text { Oxford Happiness Questionnaire } \\
\text { (mean difference: } 0.3, p=0.003 \text { ) }\end{array}$ \\
\hline Mustian $^{58}$ & $\begin{array}{l}38 \text { Breast and prostate } \\
\text { cancer patients } \\
\text { undergoing radiation } \\
\text { therapy }\end{array}$ & Usual care & $\begin{array}{l}4 \text { weeks of home-based } \\
\text { aerobic and progressive } \\
\text { resistance exercise }+ \\
\text { pedometer }\end{array}$ & NA & $\begin{array}{l}\text { Intervention was associated with } \\
\text { significantly higher } Q \text { QL scores vs } \\
\text { control post-intervention and at } 3 \\
\text { month follow-up }(p<0.05) \text {; there } \\
\text { was a trend toward lower cancer- } \\
\text { related fatigue in the intervention } \\
\text { group vs control at 3-month follow- } \\
\text { up }(p<0.05)\end{array}$ \\
\hline Vallance ${ }^{59}$ & $\begin{array}{l}95 \text { Patients with breast } \\
\text { cancer receiving } \\
\text { adjuvant chemotherapy }\end{array}$ & $\begin{array}{l}\text { Generic two- } \\
\text { page public } \\
\text { health PA } \\
\text { resource }\end{array}$ & $\begin{array}{l}\text { PA print materials, a step } \\
\text { pedometer, and a step } \\
\text { logbook }\end{array}$ & $\begin{array}{l}\text { StepsCount SC-0I } \\
\text { (StepsCount Inc., } \\
\text { ON, Canada) }\end{array}$ & $\begin{array}{l}\text { Intervention did not significantly } \\
\text { increase daily average pedometer } \\
\text { steps, light-, moderate-, or } \\
\text { vigorous-intensity PA minutes } \\
\text { or sedentary time compared to } \\
\text { control }\end{array}$ \\
\hline Von Gruenigen ${ }^{56}$ & $\begin{array}{l}27 \text { Ovarian cancer } \\
\text { patients receiving } \\
\text { adjuvant chemotherapy }\end{array}$ & - & $\begin{array}{l}\text { PA and nutrition } \\
\text { counseling at every } \\
\text { chemotherapy visit }\end{array}$ & $\begin{array}{l}\text { NL-2000 (New } \\
\text { Lifestyles Inc., } \\
\text { Lees Summit, MO, } \\
\text { USA) }\end{array}$ & $\begin{array}{l}\text { Increase in FACT-G QoL } \\
\text { score from baseline to post- } \\
\text { chemotherapy }(75.4-83.9 ; p=0.001)\end{array}$ \\
\hline
\end{tabular}

Abbreviations: FACT-G, Functional Assessment of Cancer Therapy - General; QoL, quality of life; PA, physical activity; NA, not applicable.

that PS scales that incorporate objective physical activity data will supplant existing scales in the next few decades.

\section{Fitness trackers in exercise trials}

A number of trials have tested exercise programs for cancer patients. Many recent trials testing exercise during treatment with chemotherapy ${ }^{54-56}$ or radiotherapy $y^{57,58}$ or in the survivorship setting ${ }^{24,40,59-66}$ have incorporated fitness trackers in their study design. Many of these have been randomized trials, ${ }^{24,54,55,58,61-65,67}$ and most have focused on breast cancer patients. $^{24,54,55,59,62,64-67}$ Some key findings are summarized below and in Tables 2 and 3 .

Numerous types of exercise programs have been implemented successfully in cancer patients. These have involved print materials, ${ }^{55,62}$ in-person or telephone-based counseling, ${ }^{24,40,56,61,64}$ or home-based walking, ${ }^{54}$ aerobic, ${ }^{67,68}$ or resistance training interventions. ${ }^{58}$ These studies consistently demonstrate that exercise interventions increase objectively measured physical activity using pedometry and/or accelerometry $24,61,64,67,68$ as well as self-reported physical activity. ${ }^{54,68}$ They also indicate that exercise programs may meaningfully improve patient-reported QoL scores, ${ }^{56,58}$ fatigue scores, ${ }^{40,54,58}$ self-esteem, and mood. ${ }^{54}$ In several trials, the intervention was simply the provision of a pedometer along with print materials and/or step count goals. ${ }^{57,59,60,63}$ These studies are particularly illuminating, as the exercise programs they tested require few resources and could be implemented easily in a widespread fashion. Findings largely support the role for increasing physical activity in order to improve cancer outcomes in patients undergoing active treatment and in the survivorship period.

\section{Future of fitness trackers in oncology}

While there are several forms of objective assessment of physical activity in oncology, in this review we have focused on the role of pedometers (both traditional and accelerometerbased) in assessing the PS of cancer patients. Other forms of 
objective patient assessment that can be facilitated by technology include pulse oximetry, heart rate, sleep time, posture, and body temperature dynamics. These measures, which may have some relation to physical activity levels, are currently more difficult to follow than step counts. Pedometers can be single-unit devices worn on the body or clothing continuously for over a year before requiring battery replacement. Tracking steps offer the advantage of real-time accessible feedback to both patients and their care team. Data are easily recorded, downloaded wirelessly onto computers or mobile devices, and interpreted quickly offering enhanced clinical utility over other forms of objective activity assessment.

Published data already indicate that activity information may be used as motivational tools to increase physical activity or as monitoring tools that may supplement or replace existing scales for evaluation of cancer patients' functional capacity. While fitness trackers have been studied in numerous exercise trials for patients who are likely to be cured of their malignancy, we believe that, as monitoring tools, these devices may provide particular value in patient populations who are at high risk for treatment-related toxicity and/or disease recurrence. In the future, incorporation of fitness trackers into large therapeutic trials of local or systemic therapy may reveal that activity metrics can be used to identify patients likely to benefit from specific interventions. To our knowledge, this avenue has not yet been explored.

Step counts may serve as a dynamic and objective vital sign that can be followed during aggressive treatment courses such as concurrent chemoradiotherapy to monitor for acute toxicities. In the posttreatment setting, step counts may be followed to track patients' recovery from acute toxicities and to monitor for signs of disease recurrence or late adverse events. As the capabilities of fitness trackers improve and costs fall, tracking steps in oncology stand to provide meaningful benefits to patients with minimal resource utilization. ${ }^{69}$

\section{Conclusion}

Activity metrics have advantages over both clinician assessments and PROs. Ongoing research is revealing biologic mechanisms through which physical activity may improve oncologic outcomes. Activity monitoring is now routinely incorporated into exercise studies, and we believe that step count data should be incorporated into trials of cancer therapeutics and supportive care studies as well. Tracking steps in oncology have the potential to revolutionize the way we assess and manage cancer patients in daily practice.

\section{Author contributions}

All three authors, JMP, NO and CC, made substantial contributions to conception and design, acquisition of data, analysis and interpretation of data, drafting the article, and revising it critically for important intellectual content. All three authors made a final approval of the version to be published and agreed to be accountable for all aspects of the work.

\section{Disclosure}

The authors report no conflicts of interest in this work.

\section{References}

1. National Cancer Institute [Internet]. Surveillance, epidemiology and end results program. National Cancer Institute [cited May 29, 2016]. Available from: http://seer.cancer.gov/statfacts/html/all.html. Accessed July 25, 2018.

2. National Institutes of Health [Internet]. Research portfolio online reporting tools (RePORT). National Institutes of Health [cited May 29, 2016]. Available from: https://report.nih.gov/nihfactsheets/viewfactsheet. aspx?csid=75. Accessed July 25, 2018.

3. Taylor AE, Olver IN, Sivanthan T, Chi M, Purnell C. Observer error in grading performance status in cancer patients. Support Care Cancer. 1999;7(5):332-335.

4. Ando M, Ando Y, Hasegawa Y, et al. Prognostic value of performance status assessed by patients themselves, nurses, and oncologists in advanced non-small cell lung cancer. Br J Cancer. 2001;85(11):1634-1639.

5. Hutchinson TA, Boyd NF, Feinstein AR, Gonda A, Hollomby D, Rowat B. Scientific problems in clinical scales, as demonstrated in the Karnofsky index of performance status. J Chronic Dis. 1979;32(9-10):661-666.

6. Broderick JM, Hussey J, Kennedy M, O’Donnell DM. Patients over 65 years are assigned lower ECOG PS scores than younger patients, although objectively measured physical activity is no different. J Geriatr Oncol. 2014;5(1):49-56.

7. Gotay CC, Kawamoto CT, Bottomley A, Efficace F. The prognostic significance of patient-reported outcomes in cancer clinical trials. J Clin Oncol. 2008;26(8):1355-1363.

8. Bernhard J, Cella DF, Coates AS, et al. Missing quality of life data in cancer clinical trials: serious problems and challenges. Stat Med. 1998;17(5-7):517-532.

9. Snyder CF, Aaronson NK, Choucair AK, et al. Implementing patientreported outcomes assessment in clinical practice: a review of the options and considerations. Qual Life Res. 2012;21(8):1305-1314.

10. Lee IM, Manson JE, Ajani U, Paffenbarger RS Jr, Hennekens CH, Buring JE. Physical activity and risk of colon cancer: the Physicians' Health Study (United States). Cancer Causes Control. 1997;8(4):568-574.

11. Yee J, Davis GM, Beith JM, et al. Physical activity and fitness in women with metastatic breast cancer. J Cancer Surviv. 2014;8(4):647-656.

12. Winter C, Muller C, Brandes M, et al. Level of activity in children undergoing cancer treatment. Pediatr Blood Cancer. 2009;53(3):438-443.

13. Knols RH, de Bruin ED, Aufdemkampe G, Uebelhart D, Aaronson NK. Reliability of ambulatory walking activity in patients with hematologic malignancies. Arch Phys Med Rehabil. 2009;90(1):58-65.

14. Fouladiun M, Korner U, Gunnebo L, Sixt-Ammilon P, Bosaeus I, Lundholm K. Daily physical-rest activities in relation to nutritional state, metabolism, and quality of life in cancer patients with progressive cachexia. Clin Cancer Res. 2007;13(21):6379-6385.

15. Ferriolli E, Skipworth RJ, Hendry P, et al. Physical activity monitoring: a responsive and meaningful patient-centered outcome for surgery, chemotherapy, or radiotherapy? J Pain Symptom Manage. 2012;43(6):1025-1035.

16. Phillips SM, Dodd KW, Steeves J, McClain J, Alfano CM, McAuley E. Physical activity and sedentary behavior in breast cancer survivors: new insight into activity patterns and potential intervention targets. Gynecol Oncol. 2015;138(2):398-404. 
17. Richman EL, Kenfield SA, Stampfer MJ, Paciorek A, Carroll PR, Chan JM. Physical activity after diagnosis and risk of prostate cancer progression: data from the cancer of the prostate strategic urologic research endeavor. Cancer Res. 2011;71(11):3889-3895.

18. Sternfeld B, Weltzien E, Quesenberry CP, et al. Physical activity and risk of recurrence and mortality in breast cancer survivors: findings from the LACE study. Cancer Epidemiol Biomarkers Prev. 2009;18(1):87-95.

19. Holick CN, Newcomb PA, Trentham-Dietz A, et al. Physical activity and survival after diagnosis of invasive breast cancer. Cancer Epidemiol Biomarkers Prev. 2008;17(2):379-386.

20. Holmes MD, Chen WY, Feskanich D, Kroenke CH, Colditz GA. Physical activity and survival after breast cancer diagnosis. JAMA. 2005;293(20):2479-2486.

21. Meyerhardt JA, Giovannucci EL, Holmes MD, et al. Physical activity and survival after colorectal cancer diagnosis. J Clin Oncol. 2006;24(22): 3527-3534.

22. Bonn SE, Sjölander A, Lagerros YT, et al. Physical activity and survival among men diagnosed with prostate cancer. Cancer Epidemiol Biomarkers Prev. 2015;24(1):57-64.

23. Speck RM, Courneya KS, Masse LC, Duval S, Schmitz KH. An update of controlled physical activity trials in cancer survivors: a systematic review and meta-analysis. J Cancer Surviv. 2010;4(2):87-100.

24. Pinto BM, Frierson GM, Rabin C, Trunzo JJ, Marcus BH. Home-based physical activity intervention for breast cancer patients. J Clin Oncol. 2005;23(15):3577-3587.

25. Sabiston CM, Brunet J, Vallance JK, Meterissian S. Prospective examination of objectively assessed physical activity and sedentary time after breast cancer treatment: sitting on the crest of the teachable moment. Cancer Epidemiol Biomarkers Prev. 2014;23(7):1324-1330.

26. Monga U, Garber SL, Thornby J, et al. Exercise prevents fatigue and improves quality of life in prostate cancer patients undergoing radiotherapy. Arch Phys Med Rehabil. 2007;88(11):1416-1422.

27. Cormie P, Galvão DA, Spry N, et al. Can supervised exercise prevent treatment toxicity in patients with prostate cancer initiating androgen-deprivation therapy: a randomised controlled trial. BJU Int. 2015;115(2):256-266.

28. Galvao DA, Spry N, Denham J, et al. A multicentre year-long randomised controlled trial of exercise training targeting physical functioning in men with prostate cancer previously treated with androgen suppression and radiation from TROG 03.04 RADAR. Eur Urol. 2014;65(5):856-864.

29. Champ CE, Francis L, Klement RJ, Dickerman R, Smith RP. Fortifying the treatment of prostate cancer with physical activity. Prostate Cancer. 2016;2016:9462975.

30. Schmidt ME, Meynköhn A, Habermann N, et al. Resistance exercise and inflammation in breast cancer patients undergoing adjuvant radiation therapy: mediation analysis from a randomized, controlled intervention trial. Int J Radiat Oncol Biol Phys. 2016;94(2):329-337.

31. Fischer CP. Interleukin- 6 in acute exercise and training: what is the biological relevance? Exerc Immunol Rev. 2006;12(1):6-33.

32. Godin G. The Godin-Shephard leisure-time physical activity questionnaire. Health Fit J Can. 2011;4(1):18-22.

33. Amireault S, Godin G, Lacombe J, Sabiston CM. The use of the Godin-Shephard leisure-time physical activity questionnaire in oncology research: a systematic review. BMC Med Res Methodol. 2015;15(1):1-11.

34. Godin G, Shephard RJ. A simple method to assess exercise behavior in the community. Can J Appl Sport Sci. 1985;10(3):141-146.

35. Evenson KR, Goto MM, Furberg RD. Systematic review of the validity and reliability of consumer-wearable activity trackers. Int J Behav Nutr Phys Act. 2015;12(1):159.

36. Tudor-Locke C, Williams JE, Reis JP, Pluto D. Utility of pedometers for assessing physical activity: convergent validity. Sports Med. 2002;32(12):795-808.

37. Tudor-Locke C, Williams JE, Reis JP, Pluto D. Utility of pedometers for assessing physical activity: construct validity. Sports Med. 2004;34(5):281-291.
38. Schmidt MD, Cleland VJ, Shaw K, Dwyer T, Venn AJ. Cardiometabolic risk in younger and older adults across an index of ambulatory activity. Am J Prev Med. 2009;37(4):278-284.

39. Tudor-Locke C, Ainsworth BE, Thompson RW, Matthews CE. Comparison of pedometer and accelerometer measures of free-living physical activity. Med Sci Sports Exerc. 2002;34(12):2045-2051.

40. Blaauwbroek R, Bouma MJ, Tuinier W, et al. The effect of exercise counselling with feedback from a pedometer on fatigue in adult survivors of childhood cancer: a pilot study. Support Care Cancer. 2009;17(8): 1041-1048.

41. Matthews CE, Hagstromer M, Pober DM, Bowles HR. Best practices for using physical activity monitors in population-based research. Med Sci Sports Exerc. 2012;44(1 Suppl 1):S68-S76.

42. Lee JM, Kim Y, Welk GJ. Validity of consumer-based physical activity monitors. Med Sci Sports Exerc. 2014;46(9):1840-1848.

43. Fulk GD, Combs SA, Danks KA, Nirider CD, Raja B, Reisman DS. Accuracy of 2 activity monitors in detecting steps in people with stroke and traumatic brain injury. Phys Ther. 2014;94(2):222-229.

44. Taraldsen K, Askim T, Sletvold O, et al. Evaluation of a body-worn sensor system to measure physical activity in older people with impaired function. Phys Ther. 2011;91(2):277-285.

45. Grant PM, Granat MH, Thow MK, Maclaren WM. Analyzing freeliving physical activity of older adults in different environments using body-worn activity monitors. J Aging Phys Act. 2010;18(2):171-184.

46. El-Amrawy F, Nounou MI. Are currently available wearable devices for activity tracking and heart rate monitoring accurate, precise, and medically beneficial? Healthc Inform Res. 2015;21(4):315-320.

47. Bravata DM, Smith-Spangler C, Sundaram V, et al. Using pedometers to increase physical activity and improve health: a systematic review. JAMA. 2007;298(19):2296-2304.

48. Maddocks M, Wilcock A. Exploring physical activity level in patients with thoracic cancer: implications for use as an outcome measure. Support Care Cancer. 2012;20(5):1113-1116.

49. Lowe SS, Danielson B, Beaumont C, Watanabe SM, Baracos VE, Courneya KS. Associations between objectively measured physical activity and quality of life in cancer patients with brain metastases. $J$ Pain Symptom Manage. 2014;48(3):322-332.

50. Bennett AV, Reeve BB, Basch EM, et al. Evaluation of pedometry as a patient-centered outcome in patients undergoing hematopoietic cell transplant (HCT): a comparison of pedometry and patient reports of symptoms, health, and quality of life. Qual Life Res. 2015;25(3):1-12.

51. Ma CL, Chang WP, Lin CC. Rest/activity rhythm is related to the coexistence of pain and sleep disturbance among advanced cancer patients with pain. Support Care Cancer. 2014;22(1):87-94.

52. Ohri N, Kabarriti R, Bodner WR, et al. Continuous activity monitoring during concurrent chemoradiotherapy. Int J Radiat Oncol Biol Phys. 2017;97(5):1061-1065.

53. Champ CE, Ohri N, Klement RJ, et al. Assessing changes in the activity levels of breast cancer patients during radiation therapy. Clin Breast Cancer. 2018;18(1):e1-e6.

54. Gokal K, Wallis D, Ahmed S, Boiangiu I, Kancherla K, Munir F. Effects of a self-managed home-based walking intervention on psychosocial health outcomes for breast cancer patients receiving chemotherapy: a randomised controlled trial. Support Care Cancer. 2015;24(3):1139-1166

55. Vallance JK, Friedenreich CM, Lavallee CM, et al. Exploring the feasibility of a broad-reach physical activity behavior change intervention for women receiving chemotherapy for breast cancer: a randomized trial. Cancer Epidemiol Biomarkers Prev. 2015;25(2):391-398.

56. von Gruenigen VE, Frasure HE, Kavanagh MB, Lerner E, Waggoner SE, Courneya KS. Feasibility of a lifestyle intervention for ovarian cancer patients receiving adjuvant chemotherapy. Gynecol Oncol. 2011;122(2):328-333.

57. Javaheri PA, Nekolaichuk C, Haennel R, Parliament MB, McNeely ML. Feasibility of a pedometer-based walking program for survivors of breast and head and neck cancer undergoing radiation therapy. Physiother Can. 2015;67(2):205-213. 
58. Mustian KM, Peppone L, Darling TV, Palesh O, Heckler CE, Morrow GR. A 4-week home-based aerobic and resistance exercise program during radiation therapy: a pilot randomized clinical trial. J Support Oncol. 2009;7(5):158-167.

59. Vallance JK, Courneya KS, Plotnikoff RC, Yasui Y, Mackey JR. Randomized controlled trial of the effects of print materials and step pedometers on physical activity and quality of life in breast cancer survivors. J Clin Oncol. 2007;25(17):2352-2359.

60. Frensham LJ, Zarnowiecki DM, Parfitt G, King S, Dollman J. The experiences of participants in an innovative online resource designed to increase regular walking among rural cancer survivors: a qualitative pilot feasibility study. Support Care Cancer. 2014;22(7): 1923-1929.

61. James EL, Stacey FG, Chapman K, et al. Impact of a nutrition and physical activity intervention (ENRICH: Exercise and Nutrition Routine Improving Cancer Health) on health behaviors of cancer survivors and carers: a pragmatic randomized controlled trial. BMC Cancer. 2015;15(1):1-16.

62. Short CE, James EL, Girgis A, D’Souza MI, Plotnikoff RC. Main outcomes of the Move More for Life Trial: a randomised controlled trial examining the effects of tailored-print and targeted-print materials for promoting physical activity among post-treatment breast cancer survivors. Psychooncology. 2015;24(7):771-778.
63. Mayo NE, Moriello C, Scott SC, Dawes D, Auais M, Chasen M. Pedometer-facilitated walking intervention shows promising effectiveness for reducing cancer fatigue: a pilot randomized trial. Clin Rehabil. 2014;28(12):1198-1209.

64. Matthews CE, Wilcox S, Hanby CL, et al. Evaluation of a 12-week home-based walking intervention for breast cancer survivors. Support Care Cancer. 2007;15(2):203-211.

65. Vallance JK, Courneya KS, Plotnikoff RC, Dinu I, Mackey JR. Maintenance of physical activity in breast cancer survivors after a randomized trial. Med Sci Sports Exerc. 2008;40(1):173-180.

66. Irwin ML, Varma K, Alvarez-Reeves M, et al. Randomized controlled trial of aerobic exercise on insulin and insulin-like growth factors in breast cancer survivors: the Yale Exercise and Survivorship study. Cancer Epidemiol Biomarkers Prev. 2009;18(1):306-313.

67. Jones SB, Thomas GA, Hesselsweet SD, Alvarez-Reeves M, Yu H, Irwin ML. Effect of exercise on markers of inflammation in breast cancer survivors: the Yale exercise and survivorship study. Cancer Prev Res. 2013;6(2):109-118.

68. Irwin ML, Cadmus L, Alvarez-Reeves M, et al. Recruiting and retaining breast cancer survivors into a randomized controlled exercise trial: the Yale Exercise and Survivorship Study. Cancer. 2008;112(11 Suppl):2593-2606

69. Rees GG. Cost-effectiveness in oncology. Lancet. 1985;326(8469): 1405-1408.

\section{Cancer Management and Research}

\section{Publish your work in this journal}

Cancer Management and Research is an international, peer-reviewed open access journal focusing on cancer research and the optimal use of preventative and integrated treatment interventions to achieve improved outcomes, enhanced survival and quality of life for the cancer patient. The manuscript management system is completely online and includes

\section{Dovepress}

a very quick and fair peer-review system, which is all easy to use. Visit http://www.dovepress.com/testimonials.php to read real quotes from published authors. 